\title{
An Experiment Of The Effect Of Teaching Different Computational Methods Of Operating Cash Flows On Student Understanding
}

\author{
Linda M. Nichols, Texas Tech University, USA \\ Jose Eduardo Miranda-Lopez, California State Fullerton, USA
}

\begin{abstract}
This study uses an experimental approach to determine if student understanding of the association between depreciation and cash flows differs based on which method of computing operating cash flows is presented to students. The participants are undergraduate and graduate students in business at a major university in the southwest United States. The participants attended sessions where they heard a brief lecture explaining operating cash flows using either the direct or indirect methods.
\end{abstract}

\section{INTRODUCTION}

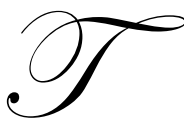

eachers of financial accounting are often frustrated by the apparent lack of understanding among many students of the relationship between depreciation and cash flows. Prior research has reflected the misunderstanding regarding the relationship between depreciation and cash flows among both undergraduate and graduate students in business (Miranda and Nichols 2007). It is important that students in business understand the difference between accrual and cash basis accounting figures. In order to achieve this, it is imperative that accounting faculty present the topic in the most effective manner.

This study uses an experimental approach to determine if student understanding of the association between depreciation and cash flows differs based on which method of computing operating cash flows is presented to students. The participants are undergraduate and graduate students in business at a major university in the southwest United States. The participants attended sessions where they heard a brief lecture explaining operating cash flows using either the direct or indirect methods. They were then presented with a complete set of financial statements for a hypothetical business and were asked to decide if they would keep the business for the next two years or if they would sell it depending on their analysis. The students had to make the proper adjustments for depreciation in order to correctly determine projected operating cash flows for the business and reach the correct decision. The results reveal that the students who attended the lecture on operating cash flows using the indirect method were better able to correctly compute cash flows and make the correct buy or sell decision.

This study contributes to the field of accounting education. Based on the results of this study, faculty teaching financial accounting should explain the difference between accrual and cash basis accounting by presenting the indirect method of reconciliation. Students understand the concept of cash basis income better when they are presented first with accrual basis income which they have an good understanding of, and then make adjustments to that income in order to compute operating cash flows.

The remainder of the paper proceeds as follows. The next section of the paper discusses related prior research. Following that are sections on research design, experimental results and finally, conclusions. 


\section{BACKGROUND AND PRIOR RESEARCH}

The importance of earnings and cash flows, both in the U.S. as well as globally, has long been a prevalent topic in the accounting literature. An early study by Beaver and Dukes (1972) found that earnings are more associated with stock returns than are cash flows. Following the release of SFAS No. 95, Statement of Cash Flows, a study by Bowen et al. (1986) found that the cash flow statement provides incremental information content relative to earnings. Dechow (1994) tested whether earnings had a stronger association with stock returns relative to net cash flows or cash from operations over short measurement intervals. Dechow found that accruals outperform cash flows in the short run, because earnings are more strongly associated with stock returns than are realized cash flows.

Other studies have attempted to determine if the superior explanatory power of earnings over cash flows generally found in the U.S. could be generalized to other countries. In order to do this, these studies tested the value relevance of earnings and cash flows across countries with different legal traditions. Bartov et al. (2001) tested whether earnings or cash flows provided more information for equity valuation within the United States, the United Kingdom, Canada, Germany and Japan. They found that earnings numbers had greater explanatory power for stock returns than did cash flow measures in the three Anglo-Saxon countries. Hung (2001) examined the relationship between the use of accruals and the value relevance of accounting measures across countries, using the investor protection laws as a benchmark. Her results indicate that the use of accrual accounting (versus cash flows) decreases the value relevance of accounting performance measures in the financial statements in countries with weak stockholder protection.

In the accounting education literature, many studies have examined the effect of presentation materials and teaching styles on student learning. Gobeil and Phillips (2001) tested whether student recall and use of facts from a case were influenced by the student's level of knowledge and the case presentation style. They found that lowknowledge students did better with narrative case materials. Clinton and Kohlmeyer (2005) tested the effect of group quizzes on student performance and learning outcomes. They found that students in the classes with group quizzes assigned higher teaching evaluations. Gujarathi (2005) examined the effect of the use of ERP software in an accounting cycle problem given in intermediate accounting. Results showed a significant positive effect from use of the software in understanding of the accounting cycle. Dempsey (2003) tested whether teaching the time value of money using mathematical functions rather than tables is more effective. Students who were taught the mathematical formulas performed significantly better on quizzes than those receiving instruction on using time value of money tables.

We examine in this study whether teaching the indirect or direct method of explaining the difference between accrual operating income and cash flow from operations is more effective in helping students understand the concept of accrual versus cash accounting. We expect that because business students are accustomed to using accrual based financial statements, they will understand cash flows better when presented with the indirect method which starts with accrual based income and adjust it to be on a cash basis.

\section{RESEARCH DESIGN}

The main research question addressed in this study is if students have a better understanding of the relationship between accrual earnings figures and cash flows when presented with the indirect or direct methods of computing cash flows from operations.

This experiment utilizes a $2 \times 2 \times 2$ between subjects experimental factorial design. The first factor which has two levels is that of method presented and is manipulated by having two separate experimental sessions. In one session, students listened to a lecture and saw examples illustrated of computing cash flows from operations using the indirect method. A second session had the lecture and examples based on the direct method of computing cash flows from operations. The same faculty member presented the lectures in both sessions.

The second factor, which also has two levels, is of depreciation method. Participants received financial statements which utilized either the straight-line or the double-declining balance method of depreciation. The third variable, which also has two levels, is that of financial statement presentation order. In half of the instruments the income statement preceded the cash flow statement while in the other half, the cash flow statement preceded the income statement. 
The participants were assigned the role of a person who just received a tomato farm as a gift from an uncle. The gift was conditioned in that the recipient could keep the farm and the proceeds for two years after which the farm would be transferred to a third party, or the recipient could sell the farm to a neighbor now and keep the proceeds. The recipients were provided with a complete set of financial statements for the farm for the previous two years. All the necessary information to project operating cash flows for the next two years and arrive at the most profitable decision was provided.

Two dependent variables are used in this study. The first is that of the sell or keep decision made based on the computation of cash flows. In half of the instruments given, the best decision would have been to keep the farm based on projected cash flows while in the other half of the instruments given, the best decision would have been to sell the farm based on projected cash flows. The variable of decision had two levels, either projected cash flows were computed correctly resulting in the best decision being reached or projected cash flows were not computed correctly resulting in a suboptimal decision. The second dependent variable is that of the main financial statement relied on. Participants were asked to explain how they reached their decision, stating which financial statement they relied on most and showing computations. The variable of financial statement relied on had three levels; the income statement, the statement of cash flows, and the balance sheet.

The student participants were both undergraduate and graduate students majoring in a business discipline. They were assigned the role of a person who just received a tomato farm as a gift from an uncle. The gift was conditioned so that the recipient could keep the farm and the proceeds for two years after which the farm would be transferred to a third party, or the recipient could sell the farm to a neighbor now and keep the proceeds. The recipients received financial statements for the farm for the previous two years.

The main hypothesis addressed by the study is:

Ho: Participants attending the presentation on operating cash flows using the indirect (direct) method will be more (less) able to treat depreciation appropriately in order to correctly compute cash flows from operations.

The experimental procedure consisted of six steps:

1. The participants listened to a presentation regarding the nature of cash flows from operations and how to compute them with numerical examples included. The presentation lasted about twenty minutes.

2. The participants read the rules, instructions, and the case.

3. The participants received the financial statements for the previous two years and the amount offered to buy the farm.

4. The participants answered questions about the statements, which were used to assess their understanding of the statements and basic accounting knowledge.

5. The participants calculated the value of the farm and decided whether to keep or sell the farm.

6. Exit questions focused on how the participants reached their decision, and provided demographic information.

\section{RESULTS}

The focal point of this study is to determine if students are better able to understand the relationship between depreciation and cash flows and correctly compute cash flows from operations when presented in the classroom with the concept of cash flows from operations under the direct or indirect methods. The principal model is a $2 \times 2 \times 2$ MANOVA, with the dependent variables of decision and main financial statement used.

In total, 127 students participated in the study. Table 1 presents the demographic characteristics of the participants. The results of chi-squared tests revealed that there were no significant differences among cells in either gender or educational level of participants. In addition, one-way ANOVA tests were performed to test for differences across treatments in questionnaire results, work experience, and time spent answering the experimental instrument. No significant differences were found. 
The results of the MANOVA are presented in Table 2. Based on a significance level of .05 , only the main effect of method presented is significant. This significance indicates that understanding of operating cash flows is influenced by the method of presentation taught, either the direct or indirect method. None of the interaction effects are significant at the .05 level.

Table 1

Demographic Characteristics $(\mathbf{N}=127)$

\begin{tabular}{|c|c|c|}
\hline Characteristics & Number & Percentage (\%) \\
\hline Gender & & 62.2 \\
\hline Male & 79 & 37.8 \\
\hline Female & 48 & 25.2 \\
\hline Academic classification & & \\
\hline Graduate & 32 & 74.8 \\
\hline Undergraduate & 95 & \\
\hline
\end{tabular}

Table 2

Overall MANOVA Results

\begin{tabular}{|l|c|c|}
\hline \multicolumn{1}{|c|}{ Effect } & F-Value & Prob. > F \\
\hline Method presented & 7.39 & $.0009 *$ \\
\hline Depreciation method & 0.99 & .3737 \\
\hline Statement order & 1.31 & .2738 \\
\hline Method/depreciation interaction & 0.32 & .7241 \\
\hline Method/order interaction & 1.11 & .3345 \\
\hline Depreciation/order interaction & 0.62 & .5371 \\
\hline Method/depreciation/order interaction & 0.68 & .5080 \\
\hline
\end{tabular}

Note: *Significant at the .05 level.

According to Cooley and Lohnes, when the MANOVA test statistic reflects significance of a main effect or interaction effect, separate univariate ANOVA designs "may suggest which of the elements of the vector variable are contributing most to the discrimination of the groups, or alternately, which variables are most affected by the treatments" (1971, p. 230). Therefore, a three factor $(2 \times 2 \times 2)$ analysis of variance was performed for each response variable.

The results of the univariate test for the dependent variable of decision are presented in Table 3 . The ANOVA results indicate a significant main effect for method presented. The participants' ability to properly compute cash flows from operations was affected by whether they attended the session presenting the direct or the indirect method of computing cash flows.

Table 3

Univariate Analysis of Variance Results For the Response Variable of Decision

\begin{tabular}{|l|c|c|c|}
\hline \multicolumn{1}{|c|}{ Variable } & df & F-value & Prob.>F \\
\hline Method presented & 1 & 3.13 & $.0003^{*}$ \\
\hline Depreciation method & 1 & 0.42 & .1735 \\
\hline Statement order & 1 & 0.06 & .8031 \\
\hline Method/depreciation interaction & 1 & 0.35 & .5571 \\
\hline Method/order interaction & 1 & 1.86 & .1750 \\
\hline Depreciation/order interaction & 1 & 0.76 & .3847 \\
\hline Method/depreciation/order interaction & 1 & 1.13 & .2929 \\
\hline Error & 119 & & \\
\hline
\end{tabular}

Note: *Significant at the .05 level.

The results of the univariate test for the dependent variable of financial statement most used are presented in Table 4. None of the main or interaction effects are significant. The main financial statement that the participants chose to base their analysis on was not affected by whether they attended the presentation on the direct or indirect 
method, if the instrument received utilized straight-line or an accelerated depreciation method, or the order in which the financial statements were presented in the instrument received.

Table 4

Univariate Analysis of Variance Results For the Response Variable of Statement Used

\begin{tabular}{|l|c|c|c|}
\hline \multicolumn{1}{|c|}{ Variable } & df & F-value & Prob.>F \\
\hline Method presented & 1 & 0.26 & .6122 \\
\hline Depreciation method & 1 & 0.04 & .8338 \\
\hline Statement order & 1 & 2.58 & .1106 \\
\hline Method/depreciation interaction & 1 & 0.39 & .5317 \\
\hline Method/order interaction & 1 & 0.19 & .6611 \\
\hline Depreciation/order interaction & 1 & 0.25 & .6209 \\
\hline Method/depreciation/order interaction & 1 & 0.14 & .7127 \\
\hline Error & 119 & & \\
\hline
\end{tabular}

The percentage of participants who correctly computed cash flows from operations and made the best buy or sell decision for each of the possible combinations of independent variables is presented in Table 4. The participants who attended the session where the indirect method of computing cash flows from operations was covered were better able to correctly compute cash flows and make the best buy or sell decision. It is disheartening to note that even when presented with the indirect method, a significant percentage of participants could not correctly compute operating cash flows and make the best decision.

Table 5

Percentage of Participants Correctly Computing Cash Flows

\begin{tabular}{|c|c|c|c|c|}
\hline & $\begin{array}{c}\text { Indirect Method } \\
\text { Presented }\end{array}$ & $\begin{array}{c}\text { Indirect Method } \\
\text { Presented }\end{array}$ & $\begin{array}{c}\text { Direct Method } \\
\text { Presented }\end{array}$ & $\begin{array}{c}\text { Direct Method } \\
\text { Presented }\end{array}$ \\
\hline & $\begin{array}{c}\text { Cash Flow Statement } \\
\text { Used Predominantly }\end{array}$ & $\begin{array}{c}\text { Income Statement } \\
\text { Used Predominantly }\end{array}$ & $\begin{array}{c}\text { Cash Flow Statement } \\
\text { Used Predominantly }\end{array}$ & $\begin{array}{c}\text { Income Statement } \\
\text { Used Predominantly }\end{array}$ \\
\hline $\begin{array}{c}\text { Straight-line } \\
\text { Depreciation }\end{array}$ & $46.667 \%$ & $53.333 \%$ & $17.647 \%$ & $29.412 \%$ \\
\hline $\begin{array}{c}\text { Accelerated } \\
\text { Depreciation }\end{array}$ & $80.000 \%$ & $53.333 \%$ & $23.529 \%$ & $37.500 \%$ \\
\hline
\end{tabular}

\section{SUMMARY AND CONCLUSIONS}

This study examined whether students understand the concept of operating cash flows better and specifically, the relationship between depreciation and cash flows, when presented with either the direct or indirect methods of computing cash flows from operations. The evidence provided by our study indicates that students better understand operating cash flows and the relationship between cash flows and depreciation when presented with the indirect method of computing cash flows. This is probably because all of the financial accounting courses revolve around accrual accounting and accrual basis income. Therefore, it is easier for students to understand cash flows when starting with accrual income which they have a firm understanding of and then adjusting that income to calculate cash basis income and operating cash flows.

The results of this study should be of great interest to accounting academicians. It is imperative that teachers of accounting present difficult concepts, such as the relationship between accrual and cash basis income, to students in a way which is easy for them to comprehend. Currently, some accounting educators present only the direct method of computing operating cash flows. This study suggests that the indirect method should be introduced to students initially until a firm understanding of operating cash flows is attained. After students achieve a firm understanding of the relationship between accrual and cash basis accounting, then the direct method of computing operating cash flows could be introduced as an alternative. Given the difficulty students have in understanding the accrual versus cash concept, accounting faculty should strive to find innovative ways to present this material. New teaching approaches in this area could result in increased student comprehension. 


\section{AUTHOR INFORMATION}

Linda Nichols joined the faculty of Texas Tech University in 1989 after completing a PhD in Accounting at Louisiana State University. She currently holds the position of Professor and Director of Accounting Programs. Her association with the oil industry began in 1980 when she worked for an international accounting firm in Houston as part of the oil and gas industry audit division. She later joined Columbia Gas Development, an exploration and production company, where she held the position of supervisor of budgeting and economics. Linda continues to be heavily involved with the oil industry through consulting and providing training for oil companies across the globe. In the past five years, she has provided industry training in Angola, Nigeria, Cameroon, Ecuador, Malaysia, Indonesia, China, Thailand, Hungary, the United Kingdom, Australia, and in the U.S. Linda is author of a BNA portfolio in Oil and Gas Accounting and co-author of a textbook in the field, Fundamentals of Oil and Gas Accounting, published by PennWell. She also serves as Associate Editor of the Oil, Gas and Energy Quarterly, and serves on the Editorial Board of the Petroleum Accounting an Financial Management Journal. Linda has published numerous articles dealing with issues of accounting for the oil industry. Since joining Texas Tech University, Linda has received both national and international recognition for her accomplishments. In 2007, she received the Texas Society of CPAs' Outstanding Accounting Educator Award, and in 999, she was chosen as Outstanding Educator of the Year by the American Woman's Society of CPAs. In 2003, she was chosen by the Fulbright Commission of the U.S. in conjunction with the government of Austria to serve as the Johannes-Kepler Distinguished Chair in International Business. Linda's service to the accounting profession includes a term as chair of the Financial Accounting and Reporting Committee of the AICPA which prepares the financial accounting and reporting section of the CPA examination. She also served as President of the South Plains Chapter of the Texas Society of Certified Public Accountants (TSCPA), and currently serves as a trustee of the Educational Foundation of the TSCPA.

Jose E. Miranda Lopez is an associate professor of accounting at California State University, Fullerton. Previously, Jose was an assistant professor and director of the finance undergraduate program at the Monterrey Institute of Technology (Tecnologico de Monterrey) in Guadalajara, Mexico. Jose holds a Ph.D. in accounting from Texas Tech University, and a M.A. in finance and a B.A. in accounting from the Monterrey Tech. His research interests are related to international financial reporting issues, and the use of accounting performance measures in different countries.

\section{REFERENCES}

1. Bartov, E., S.R. Goldberg, and M.S. Kim. 2001. The valuation-relevance of earnings and cash flows: an international perspective. Journal of International Financial Management and Accounting 12(2): 103-132.

2. Beaver, W. and R. Dukes. 1972. Interperiod tax allocation, earnings expectations, and the behavior of security prices. The Accounting Review. 47: 624-652.

3. Bowen, R., D. Burgstahler, and L. Daley. 1986. Evidence on the relationship between earnings and various measures of cash flow. The Accounting Review. 61: 713-725.

4. Clinton, B.D. and J.M. Kohlmeyer III. 2005. The effects of group quizzes on performance and motivation to learn: two experiments in cooperative learning. Journal of Accounting Education 23(2), 96-116.

5. $\quad$ Cooley, W.W. and P.R. Lohnes. 1971. Multivariate Data Analysis. John Wiley: 230.

6. Dechow, P. 1994. Accounting earnings and cash flows as measures of firm performance: the role of accounting accruals. Journal of Accounting and Economics 18: 3-42.

7. Dempsey, S.J. 2003. On the benefits of a mathematical solutions approach to time value of money instruction: arguments and evidence. Journal of Accounting Education 21(3): 239-260.

8. Financial Accounting Standards Board. 1987. Statement of cash flows. FASB: Norwalk, CN.

9. Gobeil, J. and F. Phillips. 2001. Relating case presentation style and level of student knowledge to fact acquisition and application in accounting case analyses. Issues in Accounting Education 16(2): 205-222.

10. Gujarathi, M. 2005. Use of ERP software in accounting: a teaching note. Advances in Accounting Education 7: 207-220.

11. Hung, M. 2001. Accounting standards and value relevance of financial statements: an international analysis. Journal of Accounting and Economics 30: 401-420.

12. Miranda, J. and L. Nichols. 2007. An experiment of student understanding of accruals versus cash flows. Journal of College Teaching and Learning 4(4): 53-57. 